\title{
MULTICRITERIA ANALYSIS OF REGIONAL DISPARITIES IN THE CONTEXT OF THE EU COHESION
}

\section{VÍCEKRITERIÁLNÍ ANALÝZA REGIONÁLNÍCH DISPARIT V KONTEXTU SOUDRGNOSTI EU}

\section{ING. EVA POLEDNÍKOVÁ}

\author{
Katedra evropské integrace $\mid$ Department of European Integration \\ Ekonomická fakulta Faculty of Economics \\ Vysoká ġkola báŔská - Technická univerzita Ostrava $\mid V \dot{B}$ ï Technical University of Ostrava \\ $\triangle$ Sokolská tŚda 33,701 21 Ostrava, Czech Republic \\ E-mail: eva.polednikova@vsb.cz
}

\begin{abstract}
Annotation
The paper deals with an alternative multicriteria approach to quantitative evaluation of regional development in the context of the EU cohesion. The aim of the paper is to evaluate and compare the development of regional disparities in Visegrad Four (V4) countries over the period 2001-2011 by utilizing the selected multicriteria decision-making methods. Applying TOPSIS and AHP methods we get the final ranking of V4 NUTS 2 regions based on the shortest distances to the ideal solution and the farthest from the negative ideal solution. Also, a sensitivity analysis is carried out to study the impact of different weights on the scores of relative closeness to ideal solution $\left(c_{i}\right)$ and regionsô ranking. Although some positive changes in disparities trend are observed during the examined period (especially in Poland), disparities have still persisted between NUTS 2 regions with capital cities (Praha, Bratislavský kraj, Mazowieckie, Közép-Magyarország) and more distant regions on the one hand and between Czech regions and Hungarian, Polish and Slovak regions on the other hand. The sensitivity analysis also shows that the importance of criteria influences the final ranking of regions. In the absence of the mainstream to regional disparities evaluation, this paper can be understood as a contribution to the discussion about the quantitative measurement of disparities between regions.
\end{abstract}

\section{Key words}

AHP, regional disparities, TOPSIS

\section{Anotace}

Tento !lánek se vnıuje $p$ Śedstavení alternativního vícekriteriálního pŚistupu ke kvantitativnímu hodnocení regionálního rozvoje v kontextu soudrǵnosti EU. Cílem $p$ Śsp ฤ ku je zhodnotit a srovnat vývoj regionálních disparit v zemích Visegrádské !tyŚky (V4) vobdobí let 2001-2011 s vyuğitim vybraných vícekriteriálních metod rozhodování. Pomocí metody TOPSIS a AHP získáme kone! né poŚadí region T NUTS 2 zemí V4, které je zaloǵeno na nejkratğ vzdálenosti regionu od ideální hodnoty a nejdelğ vzdálenosti od hodnoty bazální. Dále je provedena analýza citlivosti, která sleduje vliv vah kritérii na index relativní vzdálenosti $\left(c_{i}\right)$ a konel né poŚadí regionT. Aḷ koli lze, b ḩem zkoumaného období, pozorovat $n$ గkteré pozitivní zm hry ve vývoji regionálních disparit (a to zejména v Polsku), významné rozdíly stále pŚstrvávaji mezi regiony hlavních $m$ Пłt (Praha, Bratislavský kraj,

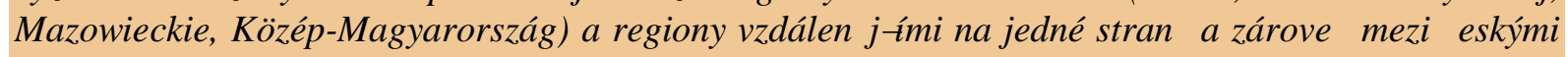
regiony a maṆarskými, polskými a slovenskými regiony na stranךdruhé. Analýza citlivosti rovnhǵ ukazuje, ğ́ rozdílné váhy kritérii ovlivŔují kone! né poŚadí regionT. V kontextu neexistence jednotného $p$ Śstupu $k$ hodnocení regionálních disparit, lze tento !lánek vnímat jako $p$ Śsp円ek $k$ diskusi o kvantitativním hodnocení regionálních disparit.

\section{Klị|lová slova}

AHP, regionální disparity, TOPSIS 
JEL classification: $\mathrm{C} 02, \mathrm{O} 18, \mathrm{R} 11$

\section{Introduction}

The economic, social and territorial disparities in the level of regional performance are a major obstacle to the balanced and harmonious development of the regions, but also of each country as well as a whole EU. The quantification of regional disparities falls into important spheres of regional policy at the state and European level. There is a general belief that differences should be kept in the sustainable limits especially since new member states have joined the EU in the years 2004 and 2007. Their admission has been associated with an increase in regional disparities that have negatively affected the EUâs competitiveness and cohesion. The elimination of disparities with the support of regional development is considered as the primary objective of the EUô development activities. In the European concept, the level of disparities can be regarded as a measure of cohesion. According to Molle (2007), cohesion can be expressed as a level of differences between countries, regions or groups that are politically and socially tolerable. We distinguish three types of regional disparities: economic, social and territorial, see e.g. Molle (2007), Kutscherauer et al. (2010). The level of regional disparities within the EU is evaluated by the selected regional indicators in the Cohesion Reports published by the European Commission every 3 years, see European Commission (2010). The main role in the support of European regional development and its funding plays the EU cohesion policy, see e.g. Molle (2007). To create a suitable methodology that enables to identify the actual level of regionô socio-economic development is the most important condition for developing effective regional policy. Therefore, the evaluation of the level of regional disparities in the EU countries are actual and important topics of many discussions and regional research studies, at the European and national level e.g. Campo, Monteiro, Soares (2008), Wishlade, Yuill (1997), Viturka, G̣ítek, Klímová, Tonev (2009), Ginevil ius, Podvezko, Mikelis (2004), Kutscherauer et al. (2010), Matlovil, Klamár, Matlovil ová (2008). Regional differences in the ñnewò EU countries, especially in Visegrad Four countries are analysed by e.g., TvrdoŔ Skokan (2011), Melecký, Poledníková (2012), Svatoǵová, Bohál ková, (2012), Tuleja (2010). Visegrad Four countries belong to the central European states where the economic development of the last 10 years has been strongly linked to European funding.

The aim of the paper is to evaluate and compare the development of regional disparities in Visegrad Four (V4) countries over the period 2001-2011 by utilizing the selected multicriteria decision-making (MCDM) methods. The sense of applying the MCDM methods is to rank and describe the changes in the V4 NUTS 2 regions reflecting their socioeconomic development in the context of the EU cohesion.

The rest of this paper is organized as follows. The approaches of regional disparities evaluation in the context of the EU cohesion are discussed in Section 1. In Section 2, the theoretical background of the methods Technique for Order Preferences by Similarity to an Ideal Solution (TOPSIS) and Analytic Hierarchy Process (AHP) are introduced. In Section 3, the empirical results of regional disparities evaluation in V4 in the year 2001 and 2011 are presented. In the last Section, the conclusions and remarks are provided.

\section{Regional disparities evaluation in the context of the EU cohesion}

The attitude of researchers towards the quantitative evaluation of regional development and disparities is not uniformed. They use several disparity indicators that are processed by different mathematical and statistical methods. From the point of view of low calculation difficulty, a high informative level and the applicability of the results in practice, traffic light method (scaling), method of average (standard) deviation, method of standardized variable, method of distance from the imaginary point are often used for measurement of disparities (Kutscherauer et al., 2010). These methods are often used in an integrated approach based on the calculation of a synthetic index of disparities, see e.g. Tuleja (2010), Svatoġvá, Bohál ková (2012). More sophisticated methods that are very useful in the process of regional disparities evaluation are multivariate statistical methods, especially cluster 
analysis and factor analysis, see e.g. Campo, Monteiro, Soares (2008), Zivadinovic, Dumicic, Casni (2009), Poledníková, Lelková (2012), Horká (2013). An alternative and not broadly extended approach to regional disparities evaluation represents multicriteria decision-making methods that helps decision maker organize the problems to be solved, and carry out analysis, comparisons and rankings of the alternatives, see e.g. Opricovic, Tzeng (2004), Tzeng, Huang (2011), Dai, Zhang (2011), Kashi (2013).

\section{Methodology}

Differences in the level of socio-economic development of V4 regions and their ranking are determined by TOPSIS method. AHP method is used to derive the weights of the regional indicators. The multicriteria evaluation of regional development takes into account the importance of the decision-making criteria. Therefore the sensitivity analysis is carried out to study the impact of the weights of criteria calculated by AHP and weights of criteria equal to one, on the scores of relative closeness to the ideal solution (ci) and regions 'ranking.

\subsection{The method TOPSIS}

TOPSIS method is based on the determination of the best alternative that comes from the concept of the compromise solution. The compromise solution can be regarded as choosing the best alternative nearest to the ideal solution (with the shortest Euclidean distance) and farthest from the negative ideal solution. TOPSIS is always used for multi-attribute decision making, by ranking the alternatives according to the closeness between the alternative and the ideal alternative (Dai, Zhang, 2011). The procedure of TOPSIS method includes the following steps. The first step is to construct a decision matrix. The decision matrix consists of a set of alternatives, $A=\{A i \mid i=1, e ́, n\}$, and a set of criteria (attributes), $C=\{C j \mid j=1$,é , $m\}$, where $Y=\{y i j \mid i=1$,é , $n ; j=1, e ́, m\}$ denotes the set of performance ratings and $w=\{w j \mid j=1, e ́, m\}$ is the set of weights for criteria. Procedure that converts all the criteria so that all of them were either minimization or maximization is often implemented before the execution of TOPSIS method. Second step is to calculate the normalized decision matrix according to formula:

$$
r_{i j}=\frac{y_{i j}}{\sqrt{\sum_{i=1}^{n} y_{i j}^{2}}},
$$

where $i=1, \ldots, n ; j=1, \ldots, m$. With regard to the defined weight of criteria, the third step of TOPSIS method is to calculate weighted normalized decision matrix expressed as vij=wj . rij, where $i=1, \ldots, n$; $\mathrm{j}=1, \ldots, \mathrm{m}$. The following step includes the determination of the positive ideal solution $(\mathrm{Hj})$ and the negative ideal solution that are derived as $\mathrm{Hj}=\max (\mathrm{vij})$ and $\mathrm{Dj}=\min (\mathrm{vij})$. Subsequently, the separation from the ideal (di+) and the negative ideal solutions (di-) between alternatives is calculated. The separation values can be measured using the Euclidean distance, which is given as:

$$
\begin{aligned}
& d_{i}^{+}=\sqrt{\sum_{j=1}^{k}\left(v_{i j}-H_{j}\right)^{2}}, \\
& d_{i}^{-}=\sqrt{\sum_{j=1}^{k}\left(v_{i j}-D_{j}\right)^{2}},
\end{aligned}
$$

Last step includes the calculation of the relative closeness to the ideal solution and rank the alternatives in descending order. The relative closeness of the $\mathrm{i}$-th alternative $\mathrm{Ai}$ is expressed as:

$$
c_{i}=\frac{d_{i}^{-}}{d_{i}^{-}+d_{i}^{+}} .
$$




\subsection{The method AHP}

Analytic Hierarchy Process is used to derive the criteria weights from paired comparison in four level hierarchic structures. The decision hierarchy structure is created; the goal of the decision is at the top level, subcriteria (group of criteria) at second level followed by the level of criteria (criteria on which subsequent elements depend). The lowest level represents a set of alternatives. Having the hierarchic structure, we compare the comparative weight between the attributes of the decision elements in form of pairwise comparison matrices. The comparisons are taken from fundamental scale that reflects the relative strength of preferences, see following table 1.

Tab. 1: Saaty's fundamental scale

\begin{tabular}{|c|c|}
\hline Intensity of importance & Definition \\
\hline 1 & equal importance \\
\hline 3 & moderate importance \\
\hline 5 & strong importance \\
\hline 7 & very strong importance \\
\hline 9 & extreme importance \\
\hline
\end{tabular}

Source: Saaty, Vargas (2012), own processing (2014)

Let $\mathrm{A}$ represent an $\mathrm{n} \mathrm{x} \mathrm{n}$ pairwise comparison matrix. The diagonal elements in the matrix A are selfcompared and thus aij $=1$, where $i=j, i, j=1,2, \ldots$, n. The values on the left and right sides of the matrix diagonal represent the strength of the relative importance degree of the $\mathrm{i}$-th element compared to the j-th element. Let aij=1/aji, where aij $>0$, i i j. After that, the normalization of the geometric mean method is used to determine the importance of elements. To ensure that the evaluation of the pairwise comparison matrix is reasonable and acceptable, a consistency check is performed. Generally, a consistency ratio (CR) can be used as a guidance to check for consistence of matrices. If the value of CR is below than the threshold of 0.1 , then the evaluation of the criteria importance is considered to be reasonable, see Tzeng, Huang (2011).

\section{Application of MCDM methods and empirical results}

Within AHP hierarchic structure, the goal is to evaluate regional disparities and assess the level of regional development in V4, the alternatives are 35 NUTS 2 regions. These alternatives are evaluated by three types of subcriteria and eight criteria shown in table 2 . These selected indicators are most frequently used regional indicators monitored within Cohesion Reports, see European Commission (2010) and are available in Eurostat database.

Tab. 2: Selected indicators for regional disparities evaluation in V4

\begin{tabular}{|l|l|c|}
\hline \multirow{4}{*}{ Subcriteria } & Criteria & Abbreviation \\
\hline \multirow{3}{*}{ Social } & GDP per capita (PPS) & GDP \\
\cline { 2 - 3 } & Disposable income of households (PPS) & DI \\
\cline { 2 - 3 } & Gross domestic expenditure on R\&D (GERD) (\% of GDP) & GERD \\
\hline \multirow{2}{*}{ Territorial } & Employment rate (\%) & UR \\
\cline { 2 - 3 } & Unemployment rate $(\%)$ & TE \\
\cline { 2 - 3 } & Persons aged 30-34 with tertiary education attainment $(\%)$ & DM \\
\cline { 2 - 3 } & Density of motorway $\left(\mathrm{km} / 1000 \mathrm{~km}^{2}\right)$ & DR \\
\hline
\end{tabular}

Source: European Commission (2010), Eurostat (2014), own processing (2014)

At first, the weights of subcriteria are calculated with respect to the goal. After that criteria are pairwise compared against the subcriteria importance. The pairwise comparison matrices reflect the author's preferences. According to final calculated weights of the criteria shown in table 3, indicators GDP per capita, disposable income and unemployment rate have the highest importance in the level of region's development and disparities evaluation. 
Tab. 3: Weights of criteria (AHP)

\begin{tabular}{|l|c|c|c|c|}
\hline Subcriteria & Weight & Criteria & Weight & Final weight \\
\hline \multirow{3}{*}{ Economic } & \multirow{3}{*}{0.731} & GDP & 0.637 & 0.465 \\
\cline { 3 - 5 } & & DI & 0.258 & 0.189 \\
\cline { 3 - 5 } & \multirow{3}{*}{ Social } & GERD & 0.105 & 0.077 \\
\cline { 3 - 5 } & \multirow{2}{*}{0.188} & ER & 0.279 & 0.053 \\
\cline { 3 - 5 } & & UER & 0.649 & 0.122 \\
\cline { 3 - 5 } Territorial & \multirow{2}{*}{0.081} & TE & 0.072 & 0.014 \\
\cline { 3 - 5 } & & DM & 0.750 & 0.061 \\
\cline { 3 - 5 } & & DR & 0.250 & 0.020 \\
\hline
\end{tabular}

Source: own processing (2014)

Table 4 shows the final ranking of NUTS 2 regions in V4 in years 2001 and 2011 based on TOPSIS method that reflects the weights (w) of criteria calculated by AHP. Table 4 presents and compares the scores of relative closeness to ideal solution $\left(\mathrm{c}_{\mathrm{i}}\right)$ and the ranks of regions of those two years, which could reveal the trends of regional disparities. On the basis of wide range value of the relative closeness that regions achieved (interval between 0.8-0.04), the significant socioeconomic differences between regions can be identified.

Tab. 4: Comparison of regions' ranking by TOPSIS in the years 2001 and 2011

\begin{tabular}{|c|c|c|c|c|c|c|c|c|c|}
\hline \multirow{2}{*}{\multicolumn{2}{|c|}{$\begin{array}{l}\text { Weight of criteria } \\
\text { Year }\end{array}$}} & \multicolumn{4}{|c|}{$\mathrm{w}=$ calculated by AHP } & \multicolumn{4}{|c|}{$\mathrm{w}=1$} \\
\hline & & \multicolumn{2}{|c|}{2001} & \multicolumn{2}{|c|}{2011} & \multicolumn{2}{|c|}{2001} & \multicolumn{2}{|c|}{2011} \\
\hline Code & Region & $\mathrm{c}_{\mathrm{i}}$ & Rank & $\mathrm{c}_{\mathrm{i}}$ & Rank & $\mathrm{c}_{\mathrm{i}}$ & Rank & $\mathrm{c}_{\mathrm{i}}$ & Rank \\
\hline CZ01 & Praha & 0.853 & 1 & 0.805 & 2 & 0.6750 & 1 & 0.6304 & 1 \\
\hline CZ02 & StŚdní L̦echy & 0.399 & 4 & 0.292 & 6 & 0.4973 & 3 & 0.3205 & 6 \\
\hline CZ03 & Jihozápad & 0.321 & 7 & 0.268 & 7 & 0.2582 & 9 & 0.2767 & 8 \\
\hline CZ04 & Severozápad & 0.243 & 12 & 0.189 & 18 & 0.2278 & 11 & 0.2206 & 16 \\
\hline CZ05 & Severovýchod & 0.307 & 8 & 0.242 & 11 & 0.2637 & 8 & 0.2734 & 9 \\
\hline CZ06 & Jihovýchod & 0.325 & 6 & 0.294 & 5 & 0.3406 & 5 & 0.3412 & 5 \\
\hline $\mathrm{CZ} 07$ & St\$́dní Morava & 0.252 & 10 & 0.229 & 15 & 0.2243 & 12 & 0.2415 & 13 \\
\hline CZ08 & Moravskoslezsko & 0.219 & 13 & 0.246 & 8 & 0.2016 & 15 & 0.2579 & 11 \\
\hline HU10 & Közép-Magyarország & 0.508 & 3 & 0.485 & 3 & 0.4276 & 4 & 0.4238 & 4 \\
\hline HU21 & Közép-Dunántúl & 0.251 & 11 & 0.184 & 19 & 0.2879 & 7 & 0.2428 & 12 \\
\hline HU22 & Nyugat-Dunántúl & 0.277 & 9 & 0.231 & 14 & 0.2542 & 10 & 0.2351 & 14 \\
\hline HU23 & Dél-Dunántúl & 0.167 & 15 & 0.104 & 30 & 0.1991 & 17 & 0.1847 & 25 \\
\hline HU31 & Észak-Magyarország & 0.149 & 19 & 0.053 & 35 & 0.1847 & 18 & 0.1181 & 33 \\
\hline HU32 & Észak-Alföld & 0.153 & 18 & 0.086 & 33 & 0.2007 & 16 & 0.1586 & 31 \\
\hline HU33 & Dél-Alföld & 0.185 & 14 & 0.124 & 27 & 0.2209 & 13 & 0.1991 & 21 \\
\hline PL11 & Gódzkie & 0.103 & 25 & 0.182 & 20 & 0.1338 & 28 & 0.2007 & 20 \\
\hline PL12 & Mazowieckie & 0.361 & 5 & 0.450 & 4 & 0.2899 & 6 & 0.3035 & 7 \\
\hline PL21 & Mağppolskie & 0.137 & 21 & 0.168 & 21 & 0.2089 & 14 & 0.2270 & 15 \\
\hline PL22 & ŚlŃkie & 0.159 & 16 & 0.238 & 12 & 0.1773 & 20 & 0.2714 & 10 \\
\hline PL31 & Lubelskie & 0.100 & 26 & 0.114 & 29 & 0.1808 & 19 & 0.1912 & 23 \\
\hline PL32 & Podkarpackie & 0.078 & 31 & 0.100 & 31 & 0.1331 & 29 & 0.1816 & 26 \\
\hline PL33 & Świňtokrzyskie & 0.071 & 33 & 0.099 & 32 & 0.1456 & 25 & 0.1696 & 29 \\
\hline PL34 & Podlaskie & 0.095 & 29 & 0.126 & 26 & 0.1498 & 24 & 0.1874 & 24 \\
\hline PL41 & Wielkopolskie & 0.155 & 17 & 0.221 & 16 & 0.1241 & 30 & 0.2073 & 19 \\
\hline PL42 & Zachodniopomorskie & 0.114 & 24 & 0.135 & 25 & 0.0859 & 34 & 0.1548 & 32 \\
\hline PL43 & Lubuskie & 0.078 & 30 & 0.146 & 22 & 0.1005 & 32 & 0.1742 & 28 \\
\hline PL51 & DolnoŜńkie & 0,137 & 22 & 0.242 & 10 & 0.1736 & 22 & 0.2127 & 18 \\
\hline PL52 & Opolskie & 0.077 & 32 & 0.141 & 23 & 0.1540 & 23 & 0.1929 & 22 \\
\hline PL61 & Kujawsko-Pomorskie & 0.099 & 27 & 0.244 & 9 & 0.1349 & 27 & 0.4719 & 3 \\
\hline PL62 & Warmiథkko-Mazurskie & 0.044 & 35 & 0.123 & 28 & 0.0983 & 33 & 0.1690 & 30 \\
\hline PL63 & Pomorskie & 0.131 & 23 & 0.196 & 17 & 0.1349 & 26 & 0.2165 & 17 \\
\hline SK01 & Bratislavský kraj & 0.699 & 2 & 0.867 & 1 & 0.5994 & 2 & 0.5231 & 2 \\
\hline SK02 & Západné Slovensko & 0.148 & 20 & 0.236 & 13 & 0.1767 & 21 & 0.1748 & 27 \\
\hline SK03 & Stredné Slovensko & 0.098 & 28 & 0.141 & 24 & 0.1048 & 31 & 0.1133 & 34 \\
\hline SK04 & Východné Slovensko & 0.060 & 34 & 0.085 & 34 & 0.0766 & 35 & 0.1001 & 35 \\
\hline
\end{tabular}


The shortest relative closeness to ideal solution is achieved by regions with capital city - Praha, Bratislavský kraj, Közép-Magyarország, Mazowieckie and region StŚední L echy. Regions Praha, Bratislavský kraj, Közép-Magyarország are ranked on the top positions and their ranking has not significantly changed till year 2011. These regions achieved the highest level of socio-economic development (especially region Praha) that implies the visible differences among regions of capital cities and the rest of V4 regions. In the year 2011, the shortest relative closeness to ideal solution was achieved by region Bratislavský kraj, following by region Praha. Also region Mazowieckie recorded visible strengthening of socioeconomic development and was ranked at fourth position. This phenomenon can be explain by the dominant position of capital city Warsaw that lies in region Mazowieckie and statistically affects the level of development of whole region. Warsaw had the highest dynamics of economic changes in the country and has been one of the fastest growing of metropolitan regions in the EU over the past few years. Within the EU cohesion policy 2014-2020 region Mazowieckie is a first region that is considered as more developed region. On the other hand, Polish regions Warmiđkko-Mazurskie, świňtokrzyskie and Slovak region Východné Slovensko can be considered as less developed compared to others. Their distances from ideal solution are the farthest and they are ranked in the last positions in the year 2001. In the year 2011 the strong weakening of all Hungarian regions development (with exception of Közép-Magyarország) was recorded. The regions Észak-Magyarország, Észak-Alföld and also Slovak region Východné Slovensko have the farthest distances from the ideal solution and they are ranked in the last positions. For the rest of regions the greater or lesser changes in disparities trend are observed during the examined period. In the year 2011, the convergence of some Polish, Czech and Slovak regions to the ideal solution is recorded (e.g. Warmiণkko-Mazurskie, Kujawsko-Pomorskie, Ğódzkie, ślŃkie, Opolskie DolnoŜńkkie, Moravskoslezsko, Jihovýchod, Západné Slovensko). On the contrary, Czech regions StŚdní Lechy, Severozápad, Severovýchod, StŚední Morava recorded visible weakening of development and their ranking got worse in the year 2011. Nevertheless, Czech regions are mostly ordered in the first half of the overall ranking. It indicates that disparities in the level of regional development have still persisted between Czech Republic on the one hand and Poland, Hungary and Slovakia on the other hand in the period 2001-2011.

Fig.1: Effect of criteria weight on scores of relative closeness to ideal solution (2001)

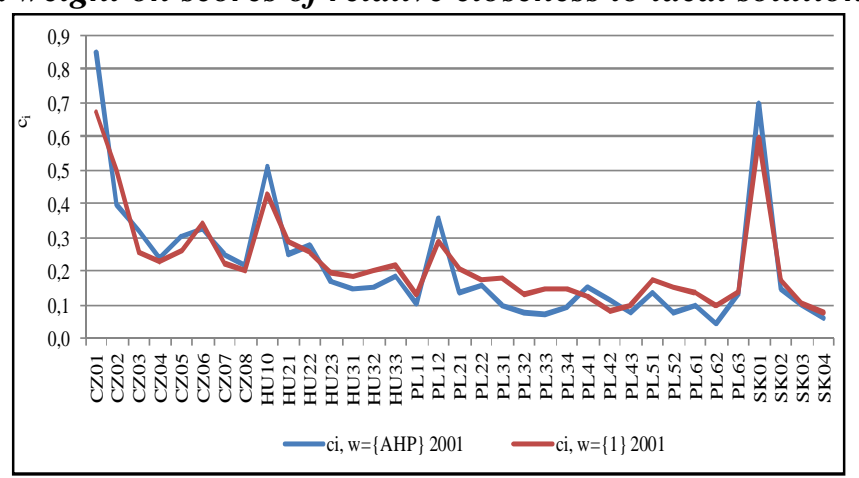

Source: own processing (2014)

Fig. 2: Effect of criteria weight on scores of relative closeness to ideal solution (2011)

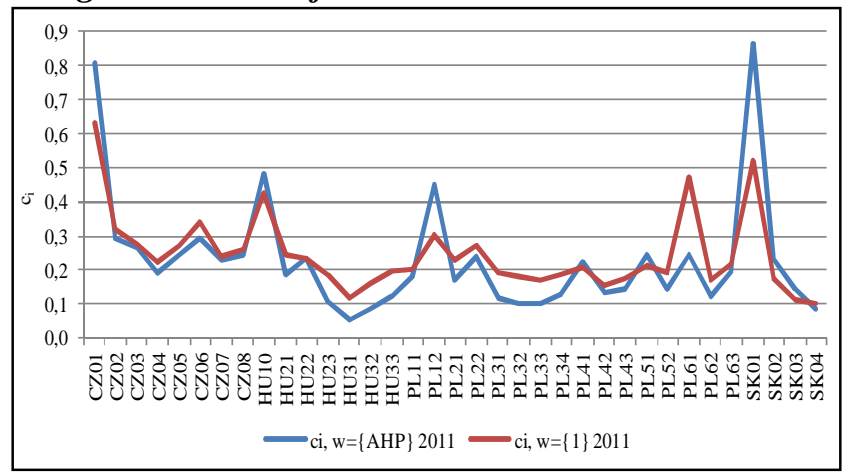

Source: own processing (2014) 
Figure 1 and figure 2 show the effect of different weights of criteria (weights of criteria calculated by AHP and weights of criteria equal to one) on the scores of relative closeness to ideal solution $\left(c_{i}\right)$. As both figures and table 4 indicate, weights of criteria have an influence on the final ranking of regions. There are differences in the ranking of regions that are considered as more developed regions, as well as less developed and average developed regions according to ranking reflecting different weights of criteria. It can be said that regions with capital city Praha, Bratislavský kraj are comprehensively developed regions because different weights of criteria had a small impact on their ranking. On the other hand, for example region Mazowieckie achieved the worse position that can imply the higher sensitivity of different criteria importance (especially GDP per capita).

\section{Conclusion}

By applying TOPSIS and AHP methods we get the final regions ranking based on the shortest distances to the ideal solution and the farthest from the negative ideal solution. TOPSIS also takes into account the relative importance of the criteria. The results of TOPSIS analysis confirm that NUTS 2 regions with capital cities (Praha, Bratislavský kraj, Mazowieckie, Közép-Magyarország) have had significant and different socio-economic positions from the other regions in V4 in year 2001 as well as in the year 2011. On the contrary, in comparison with the year 2001, the level of regional development in Hungary strongly decreased and Hungarian regions together with Slovak region Východné Slovensko were ranked in the last positions (with exception of region Közép- Magyarország) in the year 2011. These regions should focus on the higher expenditure on research and development which are major drivers of the economic growth and it also supports the future competitiveness that results in the higher GDP. The public investments in the infrastructure (transport, communication, energy), spending on the education and active labour market, including an effective utilization of subsidies from European funds, play key roles in regionsô development. Although some positive changes in disparities trend are observed during the examined period (especially in Poland), the regional disparities have still persisted between dominant regions with capital cities and more distant regions on the one hand and between Czech regions and Hungarian, Polish and Slovak regions on the other hand.

The advantage of TOPSIS and AHP methods is that they are simple, easy to use and understand. Because when making concept of suitable evaluation tools of regional development it is necessary to suggest not only difficult but also simple methods which enable quick evaluation of regional disparities by accessible tools. In comparison with the one-dimensional evaluation, multicriteria evaluation of regional development takes into account the importance and mutual dependence of the decision-making criteria. Due to importance of the criteria we are able to determine the shortest distance to the ideal solution in a more realistic way. Then the final rank of regions corresponds to the different economic, social and territorial importance of individual criteria. The sensitivity analysis shows that the importance of criteria influences the final ranking of regions (the final ranking of regions reflecting the weights of criteria calculated by AHP differs from the final ranking of regions reflecting the criteria with weights equal to one).

In the absence of the mainstream in methodological approach to regional development evaluation, the presented multicriteria evaluation can be considered as a suitable alternative of more traditional approaches.

\section{References}

[1] European Commission, (2010). Fifth Report on Economic, Social and Territorial Cohesion. Investing in Europe's future. Luxembourg: Publications Office of the European Union. ISBN 978-92-79-17800-9.

[2] Eurostat, (2014). Regional Statistics. [online] [cit. 2014-03-14]. Available at: <http://epp.eurostat.ec.europa.eu/portal/page/portal/region_cities/regional_statistics/data/database>.

[3] CAMPO, C., MONTEIRO, C.M.F., SOARES, O. J., (2008). The European regional policy and the socioeconomic diversity of European regions: A multivariate analysis. European Journal of Operational Research, vol. 187, iss. 2, pp. 600ї 612. DOI 10.1016/j.ejor.2007.03.024. 
[4] DAI, X., ZHANG, J., (2011). The TOPSIS Analysis on Regional Disparity of Economic Development in Zhejiang Province. Canadian Social Science, vol. 7, iss. 5, pp. 135-139. ISSN 1712-8056.

[5] GINEVILIUS, R., PODVEZKO, V., MIKELIS, D., (2004). Quantitative evaluation of economic and social development of Lithuanian regions. Ekonomika, vol. 65, pp. 1-15.

[6] HORKÁ, L., (2013). Factors of socioeconomic development of regions: an alternative approach to an assessment of regions. In 16th International Colloquium on Regional Sciences. Conference Proceedings. Brno: Masarykova univerzita. pp. 51ї 59. ISBN 978-80-210-6257-3. DOI 10.5817/CZ.MUNI.P210-62572013-5.

[7] KASHI, K., (2013). Utilization of Analytic Hierarchy Process in Competency Modeling. In Conference Proceedings of MEKON. Selected Papers, pp. 69-81. Ostrava: VG̈B ï Technická univerzita Ostrava.

[8] KUTSCHERAUER, A. et al., (2010). Regional disparities. Disparities in the Regional Development, their Concept, Identification and Assessment. Ostrava: VG̈-TU Ostrava. ISBN 978- 80-248-2335-5.

[9] MATLOVIL, R., KLAMÁR, R., MATLOVIL̨OVÁ, K., (2008). Development of regional disparities in Slovakia at the beginning of the 21st in the light of selected indicators. Regionální studia, vol. 2, pp. 2 ï 12.

[10] MELECKÝ, L., POLEDNÍKOVÁ, E., (2012). Use of the Multivariate Methods for Disparities Evaluation in the Visegrad Four Countries in Comparison with Germany and Austria. In ICEI 2012. Proceedings of the 1st International Conference on European Integration 2012. Ostrava: VG̈ Ï Technical University of Ostrava. pp. 199-209.

[11] MOLLE, W., (2007). European Cohesion Policy. London: Routledge. ISBN 978-415-43811-X.

[12] OPRICOVIC, S., TZENG, G.H., (2004). Compromise solution by MCDM methods: A comparative analysis of VIKOR and TOPSIS. European Journal of Operational Research. vol. 156, pp. 445-455. DOI 10.1016/S0377-2217(03)00020-1.

[13] POLEDNÍKOVÁ, E., LELKOVÁ, P., (2012). Evaluation of Regional Disparities in Visegrad Four Countries, Germany and Austria using the Cluster Analysis. In 15th International Colloquium on Regional Sciences. Conference Proceedings. Brno: Masarykova univerzita. pp. 36-47. ISBN 978-80-210-5875-0.

[14] SAATY, T., VARGAS, G. L., (2012). Models, Methods, Concepts and Applications of the Analytic Hierarchy Process. New York: Springer Science+Business Media. ISBN 978-1-4614-3596-9.

[15] SVATOǴOVÁ, L., BOHÁL̨KOVÁ, I., (2012). Methodological approaches to evaluation of regional disparities. In 15th International Colloquium on Regional Sciences. Conference Proceedings. Brno: Masarykova univerzita. pp. 11-18. ISBN 978-80-210-5875-0.

[16] TULEJA, P., (2010). Praktická aplikace metod hodnocení regionálních disparit. Acta Academica Karviniensia, vol. 1, pp. 496ï 509. ISSN 1212-415X.

[17] TVRDOœ, M., SKOKAN, K., (2011). Regional disparities and the ways of their measurement: The case of the visegrad four countries. Technological and Economic Development of Economy, vol. 17, iss. 3, pp. 501-518. ISSN 2029-4913.

[18] TZENG, G. H., HUANG, J.J., (2011). Multiple attribute decision making: methods and applications. Boca Raton: CRC Press. ISBN 9781439861585.

[19] VITURKA, M., G̦íTEK, V., KLÍMOVÁ, V., TONEV, P., (2009). Regional analysis of new EU member states in the context of cohesion policy. Review of Economic Perspectives, vol. 9, iss. 2, pp. 71ï 90. DOI 10.2478/v10135-009-0001-8.

[20] WISHLADE, F., YUILL, D., (1997). Measuring disparities for area designation purposes: Issues for the European Union. Regional and Industrial Policy Research Paper, no. 24. United Kingdom: European Policies Research Centre.

[21] ZIVADINOVIC, K.N., DUMICIC, K., CASNI, C.A., (2009). Cluster and Factor Analysis of Structural Economic Indicators for Selected European Countries. WSEAS Transactions on Business and Economics, vol. 6 , iss. 7 , pp. 331 ï 341 .

This paper is supported by the Student Grant Competition of the Faculty of Economics, V'́BTechnical University of Ostrava, project registration number SP2014/126 and by the Education for Competitiveness Operational Programme, project registration number CZ.1.07/2.3.00/20.0296. All support is greatly acknowledged and appreciated. 